\title{
The Establishment and Regulation of the Commercial Security Industry in Kenya and its Constitutionality
}

\author{
Gerald Peter Mutonyi ${ }^{1}$, Happi Kilongosi ${ }^{2}$
}

${ }^{1}$ Kenyatta University

P. 0. Box 43844-00100, Nairobi, Kenya

2 University of Nairobi

P. 0. Box 30197-00100, Nairobi, Kenya

DOI: $10.22178 /$ pos.64-2

JEL Classification: K40

Received 26.10.2020

Accepted 28.11.2020

Published online 30.11 .2020

Corresponding Author:

Gerald Peter Mutonyi

mutonyig@gmail.com

(C) 2020 The Authors. This article is licensed under a Creative Commons Attribution 4.0 License @ (1)

\begin{abstract}
The commercial security industry's effective establishment and regulation have been overlooked in many states, including Kenya. The increase of Commercial security firms' involvement in national and transnational business resulted in the United Nations drafting the Convention on the Regulation, Oversight, and Monitoring of Private Military and Security Companies.

This study examines the Commercial Security Industry in Kenya in terms of establishment and regulation, outlining the industry's major issues and challenges. The aim was to demonstrate that laws and practices relating to registration and regulation of the Commercial Security Industry in Kenya are loosely created, weak, and shaky. And up to date, the commercial security industry in Kenya is operating in contravention of the Constitution.
\end{abstract}

Keywords: commercial security; commercial security firms; security; laws; regulations.

\section{INTRODUCTION}

After introducing the neoliberal philosophy, which was an offshoot of Washington Consensus policy, commercialisation hit even areas considered the exclusive domain of the state, such as security. With the trend of commercialising security becoming national and international, the commercialising of security services gained prominence worldwide. In that regard, this investment sector has influenced and has become an area of concern to scholars and policy-makers at national and international levels. The commercial security industry (CSI) comprises enterprises that offer some policing/security services with a profit motive. Commercial security can be described as contracted fee-paying services to protect persons and physical assets $[2,13,16]$.

In light of this study, the commercial security industry and private security industry may differ in the nature and range of contracts between the consumers and providers. Therefore, this study will confine itself to the term of the commercial security industry. The CSI has been a fastdeveloping socio-economic sector, but it seems to have been forgotten by policy and law-makers in Kenya. There is a complete break between commercial security firms (CSFs) and the regulatory framework established to standardise their country's activities.

This paper proposes two main points of views: first, that the Constitution of Kenya does not envision commercial actors in the sphere of policing, consequently sanctioning CSFs to operate in Kenya is an unconstitutional allocation of exclusive authorities of the state and a contradiction to the 'Weberian model of State' which enjoyed the monopoly of the legitimate use of physical violence [10]. Second, non-effective regulated CSI can be compromised by people and groups not registered and licensed, hence constituting a higher security risk for the country.

The commercial security industry has been automated through security associations until late 2016. After that, the PSRA, No 13 of 2016, paved 
the way for the formation of an authority to oversee commercial security practice in Kenya.

Research Methodology. The study adopted an explanatory research design. It then used three data collecting methods: library research, internetbased and scheduled interviews.

\section{RESULTS AND DISCUSSION}

Laws of Private Security Industry in Kenya. There is a particular piece of legislation or statutory (regulatory) authority that is supposed to govern the CSI activities. However, the commercial security industry is still self-regulating through security associations Kenya Security Industry Association (KSIA) and Private Security Industry Association (PSRA). After that, the PSRA, No 13 of 2016, was expected to pave the way for the formation of an authority to oversee the practice of commercial Security in Kenya.

Establishment and Regulation of Commercial Security Firms. Commercial security firms (CSFs) are registered like other business entities as per the Companies Act 2015. However, there are no special procedural steps the holder of a certificate of incorporation must fulfil to be permitted to provide security services in Kenya. To set up a security business should be quite different from ordinary commercial enterprises. This is because allowing a commercial security firm to operate, several security concerns need to be considered. In addition to conditions under the Companies Act, the applicant must meet other stringent criteria set by the law.

The foremost concern is that, after a CSF is issued with a license, no government institution or agency is directly in charge of its operations. Besides, most of the CSFs are founded, owned, and operated by current serving members and exmembers of the civil service, disciplined forces most having influential political networks in one way or another, thereby blocking any move towards effective regulation of the CSI. For example, former Judiciary Chief Registrar Gladys Shollei was accused of having used her influence to award a CSF associated with her to earn a government contract []. Coincidentally, she chaired the committee on delegated legislation that recommended the annulment of the Private Security Industry Regulations 2019, which the PSRA Authority had intended for the code of practice and procedures for the industry []. One of the officials of PROSAK a reputable association for security practitioners, had this to say:

"They use their networks to undercut other commercial security firms by offering what is way below market rates, and that way, they pay their personnel peanuts, and the repercussion is the delivery of poor services from unmotivated guards".

This approach would indicate that those who would be expected to ensure that the industry is operating at high moral and professional levels are instead derailing the industry to maximise their profit margins. The repercussions would be, security personnel are inclined in not benefitting as rivalry in the market makes security firms to reduce what they charge for services rendered [1]. In this regard, the commercial security guards will not be encouraged to undertake their obligations to the best of their abilities. They might be compromised to get involved in illegal activities like allowing the exit of unauthorised goods so that they earn a commission from the arrangement.

This shared practice by most of the CSFs contradicts Victor Vroom's theory of expectancy. A worker trusts that the more effort they put in, the superior the performance, and with the outstanding performance, the higher will be the payment [17]. It also challenges Abraham Maslow's theory of the hierarchy of needs that employment is a significant base of monetary security. The better the remunerating career is, the more monetarily secure an individual becomes [6]. It also contradicts another study that commercial security guards should be paid a salary at least within the minimum government requirement [9].

The second concern is how these public officials draw a line between their commercial policing errands (managing their firms) and their public policing responsibilities. Instead, there arise several complications, such as split loyalty, conflict of interest, and the likelihood of using public offices for personal gain. Since CSIs are currently supposed to be regulated by the parliament, selfregulating or by the consumers, within the CSI we have politicians who own CSFs and have access to information concerning CSI, and this may lead to; one misuse of accountability information especially where such information is against their commercial interests.

When the owners of a CSF are the same as the consumers of service due to their position in 
Government that makes it possible to award their own firms contracts, thereby compromising their impartiality in creating and implementing decisions relating to the regulation of CSI especially in delivering strategies or advocating for new laws, also, if a CSF owned by a public servant engages in somewhat in a scandal, it may discredit the particular officer. Eventually, the public's confidence in the public servants may dent even further ${ }^{1}$. Two, they may use confidential information against rival firms, and three, for blackmailing prospective consumers to agree to take their services or shield their consumers' interest.

The third concern is that the companies Act does not make any prohibitions on the activities entering into when running a security firm. The repercussions are that firms registered as security companies are providing services and goods that are not related to security include activities like supplies of non-security stationery and even public transportation of passengers. A director of a security firm pointed out that.

"The industry is competitive and challenging, especially when you have not been able to penetrate and established yourself. That makes some of us engage in other activities so as we may be able to cater for our sustenance".

This practice forces the industry to engage in businesses that are not their core business. Even when any dishonour arises due to the malpractice or noncompliance of that firm on meeting its customer obligation, the CSI image is tarnished. The citizens will not be convinced that the firm was engaged in providing other services and goods not related to security, for example, housekeeping.

As we have discussed above, the establishment and regulation process has some weaknesses compared to other international principles of standardising CSFs. The commercialised Security industry and its activities in South Africa's Security are under a code of conduct for security services providers fixed by the Private Security Industry Regulatory Authority (PSIRA): It is the su-

1 THE PUBLIC OFFICER ETHICS ACT, 2003 prohibits public officers from awarding contracts, or influence the award of a contracts, to themselves, their spouse or relative, or business associate; engage in any occupation or business which might prejudice their status as public servants, and not engage in private business during official working hours. pervisory arm for the South African PSI set up by the Private Security Industry Regulation Act, No. 56 of 2001.

In Russia, regulation over CSFs is implemented by the ministry of the interior and the prosecutor general's office ${ }^{2}$. In Ukraine, the ministry of the interior is in control for the regulation of the commercial security industry, including the issuance and withdrawal of licenses. In Georgia, the retail security industry is weakly regulated, mainly because of the lack of specific CSF legislation. Therefore, it is practically no likelihood of guaranteeing that the principles are upheld throughout the industry in Georgia [4].

An example of self-regulation in the sector is with the British Security Industry Association (BSIA), which has taken actions to inspire some minimum principles and is authorised to administer the current law on the commercial security industry. The BSIA develops the regulations, which afterwards passes it on to the British Standards Institution (BSI) for enhancement as a British Standard ${ }^{3}$.

There is no national arrangement on regulation in the USA as the states differ in a significant way in their needs. Some states have no regulatory oversight, whereas some states regulate guards armed with firearms only [15]. Some use indigenous police agencies to control the commercial firms, although others encourage the industry to self-regulate.

The Private Security Industry under the Constitution of the Republic of Kenya. The Constitution of the Republic of Kenya, Chapter 14, Article 239(4) [18] prohibits persons from establishing a military, paramilitary, or similar organisation that purports to promote and guarantee national security, except as provided for by the Constitution or an Act of Parliament of Kenya.

\footnotetext{
${ }^{2}$ Law of 11.01 .1991 on private detective and guarding activities in the Russian Federation (amended by Federal laws of 21.03.2002, 10.01.2003 and 06.06.2005); Law on licensing particular types of activities (08.08.2001 No 128-fz.), Governmental decree on licensing non-governmental (private) guarding and detective activities (14.08.2002, No 600), order of the Ministry of the Interior regulating the use of fire arms (13.04.2005, No 275) as well as on training (31.12.1999).

3 British Security Industry Association-overview https://www.bsia.co.uk/Portals/4/Publications/302bsia-overview.pdf.
} 
It is only the Government that is permissible to recruit and preserve any disciplined forces of various types for resistance and security on the territory and the people. This conception of a state's responsibility falls directly in the 'Weberian' model of a condition that maintains a monopoly on the legitimate use and allocation of legitimate force.

The first question to be probed is whether the CSFs qualify as armed forces under Article 238? Accurately, the CSFs qualify as a disciplined force, although not so explicitly stated under Article 238. This is for the following reasons. First, the state action doctrine, the CSFs qualifies as armed forces (state actors), not because of the arrangement but the function they perform and legitimise directly or indirectly by the state to fulfil public demand for order and security [11]. The state action doctrine does not shield persons' rights to be free of state control but instead protects the citizens' right to democratically decide the kind of social order they would desire to stay in. It is not for the respect of the citizen's rights, but the respect for democracy, which has higher stakes.

Second, the arm of the state theory affirms that whenever a commercial provider acts as an arm of the Government by accomplishing a public call for order and security, that commercial supplier ought to be held to be a de facto state actor [11]. In the Kenyan context, various activities performed by CSFs are more or less comparable to those of the state security agencies. For example, the prevention of law-breaking, protection of people and property, and investigations make CSFs an attachment of the state or de facto state security agency. Incorporation of commercial players in responsibilities, which are the state's jurisdiction, makes that player an arm of the Government [11].

Third, CSFs are abided by the disciplined forces' behaviours, cultures, and principles such as saluting, marching, and parades), usage of accessories of the state security agencies (walkie talkie radio sets, whistles, and lanyards), and undergo upgraded teachings and exercises which program them to have similarities like state security agents [7].

Besides, just like in the disciplined forces, CSFs have an established chain of command of duty, a culture of loyalty, a set of rituals, beliefs, and symbols. This opinion was also held by the American Civil Liberties Union of Virginia, Inc (amicus curiae) in the USA v. Mario Terrell Day ${ }^{4}$. The contention was whether the commercial security guards should be considered state players for the 4th and 5th Amendments of the USA Constitution. The amicus curiae responded to that issue in the affirmative and consequently pronounced that commercial security guards conduct themselves more like state security agents than they behave like a regular citizen. For instance, they have powers to detain persons; they undertake searches and freaks; they investigate incidents and undertake to uphold law and order. Two, commercial security guards are often mistaken for state security agents as they tend to use the indicia (indications) of authorised power to convince citizens' obedience. Three, commercial security guards are officially predisposed to look and act as police officers 5 . Four, commercial security personnel bear the imprimatur (official permission) of the state because protecting the citizens from internal and external threats is a principal obligation of the state ${ }^{6}$. Therefore, CSFs qualify as de facto state security agents because they execute some controls that have been by tradition associated with sovereignty ${ }^{7}$.

The second question is, are the existence of CSFs in conformity with the Constitution? Since CSFs qualifies as armed forces as discussed above, the answer is that commercial security firm's presence in Kenya is unconstitutional and illegal due to the following explanations:

First, under chapter 14, Article 239(4) of the Constitution, only the Government is empowered to establish an armed force of any kind as provided for by the Constitution or an Act of Parliament of Kenya. The provision asserts that,

"A person shall not establish a military, paramilitary, or similar organisation that purports to promote and guarantee national security, except as provided for by this Constitution or an Act of Parliament" [18].

\footnotetext{
${ }^{4}$ F.3d , 2010 WL 60900 (4th Cir. Jan. 8, 2010), on Appeal from the United States District Court For the Eastern District of Virginia Richmond Division.

5 Ibid.

${ }^{6}$ Loc. cit.

7 Justice Rehnquist in Jackson v. Metropolitan Edison Co. (1974) 419 U.S. 345.
} 
CSFs as commercial players neither established by the state nor reporting to the state are unconstitutional for violating Article 239(4).

Second, CSFs operate outside the framework of the law. They are taking a precede from Tanzania where judge Mwalusanya in determining the constitutionality of 'traditional army' (sung), held them unconstitutional for operating in a vacu$u^{8}$. Therefore, applying judge Mwalusanya's formulation on commercial bodies that function outside of the legal structure, CSFs come to be unconstitutional as they lack the statutory basis upon which to operate. The Constitution of the United Republic of Tanzania (the Constitution) under Article 147 (1 and 2) prohibits individuals, organisation, or group of persons except for the Government from raising or maintaining an armed force of any kind in the United Republic of Tanzania for the defence and security of the territory and the people of Tanzania9. In the South African scenario, the Constitution of the Republic of South Africa Article 199(3) allows armed organisations or services such as CSFs to be in business but under specific national legislation for structure and regulation.

Third, the Constitution of Kenya does not of any kind insinuate the delegation of maintenance of security and policing powers to commercial entities. This premise is supported by the ruling of the Israel High Court of Justice in the Human Rights Program versus the Minister of Finance (alias Academic Center of Law and Business, Human Rights Division versus Minister of Finance) ${ }^{10}$. In this case, the petitioner asked the

${ }^{8}$ Misperesi K. Maingu v. Hamisi Mtongori \& 9 Others, HC at Mwanza, Civil Case No, 16 of 1988; Geza Geza \& 12 Others v. Isa Hamisi \& 11 Others, HC at Mwanza, civil Case No. 7 of 1988; Charles Mwita \& Another v. Kando Mresi \& 10 Others, HC at Mwanza, Civil Case No. 15 of 1988; Charles Charari Maitari v. Matiko Chacha Ghati \& 4 Others; and Ngwegwe s/o Sangija \& 3 Others v. R., HC at Mwanza, Criminal Appeal No. 72 of 1987 [All cases reported in Peter, C.M. \& H. KijoBisimba (2005) Justice and Rule of Law in Tanzania: Selected Judgments and Writings of Justice James L. Mwalusanya and Commentaries. LHRC].

9 The Constitution of the United Republic of Tanzania, 1977.

10 4(2009) HCJ 2605/05 (Israeli Supreme Court sitting as the High Court of Justice) available at: <http://elyon1.court.gov.il/files/05/050/026/n39/0 5026050.n39.pdf> (in Hebrew). Seven Judges concurred, whilst, Justice Edward Levy dissented, holding
High Court of Israel to pronounce an Amendment to the Prisons Ordinance ${ }^{11}$, illegal for permitting commercialisation of prisons in violation of Article 1 of Israel's Basic Law. The High Court of Israel held for the petitioner by declaring prison's commercialisation scheme null and void in its totality attributable to, one, that conventionally the state has incarceration powers as captured under the social contract principle. Consequently, the state as a voted body and democratically accountable body should hold the monopoly over the exercise of controlled power planned to advance the public's interest, for instance, democratic mandate theory [5]. The state cannot give its legitimate responsibilities of enforcing the law and security of the citizen's safety to commercial players who are guided by profit-making objectives $[5,12]$. The Court rejected the state's reasoning that commercialisation (of prisons) is a simple economic strategy that cannot tremble the fundamentals of the organisation of the Democratic Governance and the basic values of the legal system [12].

Fourth and lastly, the security agents in Kenya are held to constitutional accountability by Article 59(2)(d) of the Kenya National Human Rights and Equality Commission. It mandates the commission to monitor, investigate, and report human rights observance in all spheres of life in the Republic, including keeping by the national security organs. It is noted that only the security agents that we recognised in the Republic of Kenya are the national security organs in Article 239(1), names as the Kenya Defence Forces, the National Intelligence Service, and the National Police Service. Commercial security firms are not mentioned anywhere, thereby alluding to the fact that they are not constitutionally recognised. Even with the enactment of the Private Security Regulation Act (PSRA) No 13 of 2016, the Constitution will still have to be amended to make the new entrant of the CSFs legitimate and therefore to receive oversight by the Kenya National Human Rights and Equality Commission. There is an argument that commercial security workers ought to be held to the Bill of Rights [11]. "Both official police and private police functioning as arms of the state should be held to constitutional standards because they have been legitimised,

that the Court cannot nullify a privatization scheme which is yet to be implemented.

${ }^{11}$ Amendment No. 28 of 2004. 
directly or indirectly, by the state, to fulfil a public demand for order and security" [11].

From the perspective of the above argument, the Act of the Kenya government to permit CSFs to be in business violates the legitimate right to security of citizens and property and therefore amounts to the unlawful allocation of public powers to commercial actors. Accordingly, commercial security is the foremost frontier of safeguarding for the citizen and needs to be well regulated [8].

To legitimise the activities of the CSFs in Kenya, the state adopted a model to legitimise them through an Act of parliament. Private Security Regulation Act (PSRA) No 13 of 2016 to ensure that the industry operates responsibly and professionally. However, the authority that was envisioned to oversee the Act's implementation has not had its house in order. It is currently facing a hurdle after parliament annulled the regulations the authority had proposed to implement the Act.

In that regard, unless Article 239 of the Constitution is amended to incorporate other players in the security sphere, the existence and operation of CSFs in Kenya will be illegal. The only way to legalise CSF's activities in Kenya is to constitutionalise them by adopting the South African model. In light of those above, the Private Security Regulation Act (PSRA) No 13 of 2016 will not be perceived as going against Article 239(4) of the Constitution.

\section{CONCLUSION}

The Kenyan commercial security industry came into existence in 1980 due to the neo-liberal policies that saw the state security agencies being under-funded and losing the ability to deliver services, including security provision. The guidelines then advocated for the liberalisation of inward foreign direct investment and abolition of regulations that impede market entry. As a result, no law, circular, administrative order, or proclamation made official CSF's activities in Kenya. Introducing key players such as the CSFs without any legislation or regulation was an error that needs correction.

This study evaluated Kenya's commercial security industry and concluded that the industry has some weaknesses in terms of registration and regulation. Above all, the chapter ignites a discussion about the constitutionality or otherwise the legitimacy of CSFs activities in Kenya. Furthermore, laws and regulatory frameworks have not kept pace with the expansion of commercial security. Other stakeholders would be contented that commercial security firms are already being held answerable both criminally and civilly by their clients. But others have argued that commercial security has to be laid open to the same form of democratic controls and accountability as the other state security organs in Kenya. Therefore, the increased 'marketisation of insecurity control' in Kenya requires a constitutionalisation of the commercial security industry's governance.

\section{REFERENCES}

1. Abrahamsen, R. (2010, July 1). Privatising Africa's Everyday Security. Retrieved from https://www.opendemocracy.net/en/opensecurity/privatising-africas-everyday-security

2. Boemcken, M. (2011). Commercial Security and Development: Findings from Timor-Leste, Liberia and Peru. Retrieved from https://www.bicc.de/uploads/tx_bicctools/brief45.pdf

3. Daily Nation (2019, December 1). MPs thwart security guards minimum wage bid. Retrieved from https://www.facebook.com/EagleNewsStreamKe/posts/mps-thwart-security-guardsminimum-wage-bidmps-have-opted-to-deny-500000-securit/2877754558915592/

4. Hiscock, D (2006). Post-Soviet private security: the commercialisation of security. In M. Caparini, A. Bryden (Eds.), Private actors and security governance (pp. 199-140). Zurich: LIT-Verlag\&Co.

5. Ludlow, A. (2010). Prison Privatisation in Israel: Important Transnational Lessons. Cambridge Student Law Review, 326-329. Retrieved from https://heinonline.org/HOL/LandingPage?handle=hein.journals/camslr6\&div=30\&id=\&page=

6. Maslow, A. (1970). Motivation and personality (2nd ed.). Reading: Addison-Wesley.

7. Montgomery, R., Griffiths, T. (2015). The Use of Private Security Services for Policing. Retrieved from https://www.publicsafety.gc.ca/cnt/rsrcs/pblctns/archive-2015-r041/2015-r041-en.pdf 
8. Mutonyi, G. P., \& Sirera, A. (2018). Commercial Security's' Effect on Security of Kenyans in Private Venues. Emerging Science Journal, 2(4). doi: 10.28991/esj-2018-01142

9. Mutonyi. G. (2016). Private Security Guards'Job Retention Determinants in Kenya. Saarbrucken: Lambert Academic Publishing.

10. Lottholz, P., \& Lemay-Hébert, N. (2016). Re-reading Weber, re-conceptualising state-building: from neo-Weberian to post-Weberian approaches to state, legitimacy and state-building. Cambridge Review of International Affairs, 29(4), 1467-1485. doi: 10.1080/09557571.2016.1230588

11. Enion, M. R. (2009). Constitutional Limits on Private Policing and the State's Allocation of Force. Duke Law Journal, 59(3), 519-53.

12. Sommer, H., Seidman, G. (2010). The Unconstitutionality of Privatized Prisons-Lessons Learned from the Israeli Experience. Retrieved from https://www.prisonlegalnews.org/media/publications/interdisciplinary_center_the_unconstitu tionality_of_privatized_prisons_israeli_report.pdf

13. Sparrow, M. (2014). Managing the Boundary Between Public and Private Policing. Retrieved from https://www.ncjrs.gov/pdffiles1/nij/247182.pdf

14. N. d. (2015, January 8). I have no link to firm guarding courts, says Gladys Shollei. Retrieved from https://www.standardmedia.co.ke/article/2000147064/i-have-no-link-to-firm-guardingcourts-says-gladys-shollei

15. Strom, K., Berzofsky, M., Shook-Sa, B., Barrick, K., Daye, C., Horstmann, N., \& Kinsey, S. (2010). The Private Security Industry: A Review of the Definitions, Available Data Sources, and Paths Moving Forward. Retrieved from http://www.ncjrs.gov/App/publications/abstract.aspx?ID=254874

16. United Nations Office on Drugs and Crime (2014). State Regulation concerning Civilian Private Security Services and their Contribution to Crime Prevention and Community Safety. Retrieved from https://www.unodc.org/documents/justice-and-prisonreform/crimeprevention/Ebook0.pdf

17. Vroom, V. (1964). Work and motivation. New York: Wiley.

18. National Council for Law Reporting with the Authority of the Attorney General. (2008). The Constitution of Kenya. Retrieved from https://kfcb.co.ke/wpcontent/uploads/2016/07/Constitution.pdf 